\title{
Metastatic Gastric Carcinoma
}

National Cancer Institute

\section{Source}

National Cancer Institute. Metastatic Gastric Carcinoma. NCI Thesaurus. Code C153320.

A gastric carcinoma that has spread from its original site of growth to another anatomic site. 